\title{
ШТРИХИ ДО ПОРТРЕТІВ МІНІСТРІВ ВНУТРІШНІХ СПРАВ: ПОГЛЯД ОСОБИСТИЙ, АЛЕ НЕ ТРИВІАЛЬНИЙ \\ (3 приводу книги Олександра Бандурки «Міністри внутрішніх справ теж люди». Харків: Майдан,2020.299 с.)
}

\section{ГРЕЧЕНКО Володимир АНатолійович - доктор історичних наук, професор, заслужений працівник освіти України}

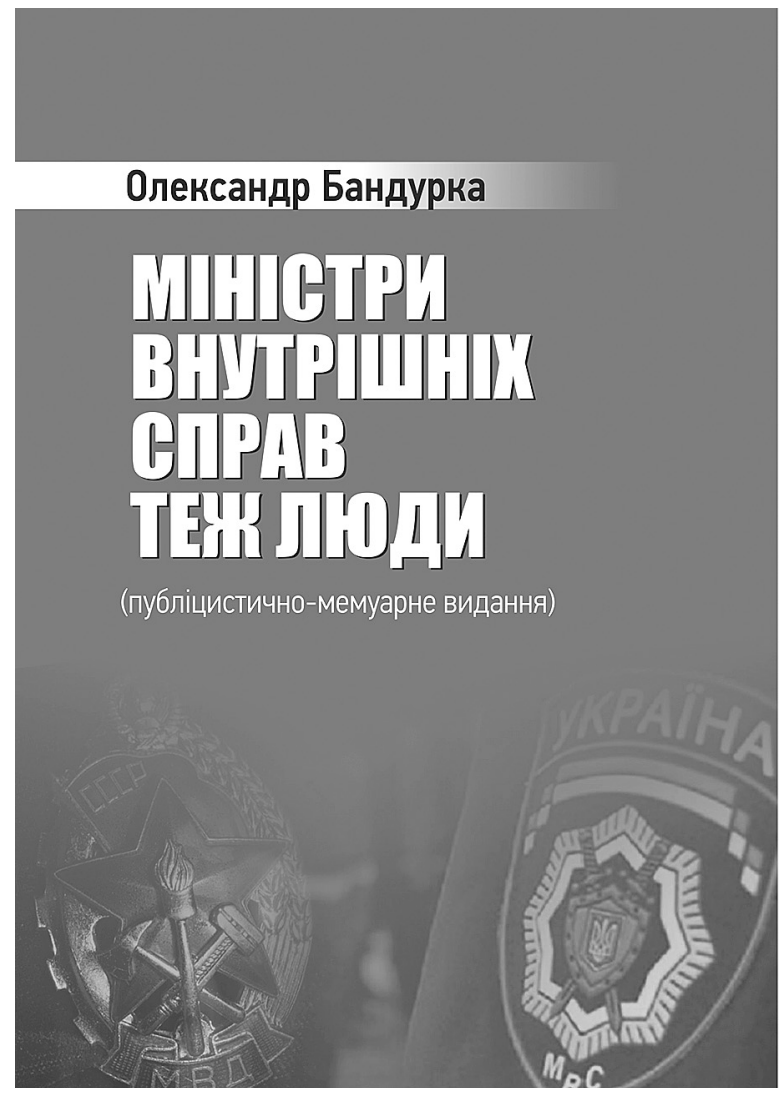

Ми пишемо не історію, а біограббї, $i$ не завжди в найславніших діяннях буває видно чесноти чи порочність, але часто який-небудь незначний вчинок, слово чи жарт краще виявляють характер людини, ніж битва з десятками тисяч убитих, величезні армї та облоги міст.

Плутарх
Ці слова, взяті нами для епіграфу, були написані Плутархом майже 2 тисячі років тому. У своїх прославлених «Порівняльних життеписах» він порівнюе і «зіставляє» біографії античних знаменитостей, де підводиться певний підсумок, підкреслюється схоже і різне у видатних представників стародавніх римлян та греків. Його робота була настільки популярною, що і через 18 століть Наполеон Бонапарт постійно носив iii iз собою (як Олександр Македонський «лліаду» Гомера). Плутарха більше цікавили особистісні якості видатних людей (з метою дати позитивний приклад для наслідування, іноді він навіть прикрашає портрети своїх героїв). 3 того часу дослідження, нариси, спогади про «сильних світу цього» стали одним 3 найпопулярніших жанрів історичної літератури. Серед найвидатніших таких пам'яток можна згадати нариси Миколи Костомарова, зібрані в серії «Руська історія в життеписах їі найголовніших діячів» чи відому радянську серію «Життя знаменитих людей» (ЖЗ $\Lambda)$. Aле у XXI ст. на зміну повчальній «історії героїв» прийшов інтерес до того, що називають «малими життєвими світами», а отже, кожну біографію стали розглядати як вияв неповторного - за висловом відомої української історикині Наталії Яковенко, - «призму, через яку переломлюються соціальні мікропроцеси та миттєві тенденції й унікальний життєвий досвід індивіда, його внутрішне самовідчуття і стиль поведінки, що під- 
штовхують до саме такого, а не інакшого життєвого вибору».

Акцент на індивідуальному, зрозуміло, потребує мікроаналізу, тобто щільної фіксації не тільки життєвого шляху, а й свідомості індивіда. Але як говорив знаменитий давньогрецький філософ Геракліт: «Кінця душі не знайдеш, пройшовши весь шлях, - така вона глибока».

Спогади Олександра Бандурки цікаві як розповіді про минуле, що грунтуються на особистому досвіді та пам'яті мемуариста. Порівняно 3 іншими джерелами особового походження саме в мемуарах найпослідовніше та найповніше реалізується історична самосвідомість особистості - у цьому й полягає специфічна соціальна функція мемуарів як виду джерел. Особливістю цих спогадів є їх документальність, яка базується на свідченнях автора та сучасників подій. Однак ці нариси - це не тільки об'єктивна фіксація фактів минулого, але й певна сповідь, пояснення і роздуми особистості. Як і кожні мемуари, ці теж суб'єктивні. Проте ця суб'єктивність спогадів є їхньою властивістю, яка й робить їх неоціненним матеріалом для здійснення біографічного дослідження (адже вказані мемуари містять унікальні факти та деталі як із життя автора, так і його сучасників).

Як відомо, цінність спогадів як джерела біографічних досліджень залежить від багатьох чинників, в тому числі від того, яку роль відігравав сам автор у описуваних ним подіях, від гостроти сприйняття ним дійсності, від його здатності запам'ятати перебіг подій, від часу їх написання. У цих замальовках реалістично відображаються деталі життя автора та його сучасників не лише в громадсько-політичній роботі, а й у буденному житті, в сім’і, колі друзів, у години дозвілля - саме про це й говорив Плутарх. Перед нами постають живі особистості 3 їх духовним світом та індивідуальними рисами характеру, емоціями, амбіціями, пошуками і сумнівами, звичайними людськими слабкостями й недоліками. У цьому безсумнівна заслуга автора рецензованої роботи - йому вдалося показати не чорно-білі світлини, а портрети різних людей з відтінками різних барв.
Це стало можливим тому, що Олександр Бандурка знає службу в МВС досконало, обіймав посади слідчого, оперативного працівника, заступника i начальника різних районних і міських органів внутрішніх справ, обласних управлінь, керував найбільшим галузевим управлінням в Міністерстві внутрішніх справ, навчався в Академії управління МВС СРСР. Йому випало спілкуватись або тривалий час працювати як 3 міністрами внутрішніх справ МBC СРCP, так із міністрами внутрішніх справ УРСР, а нині України.

Готуючи ці спогади, автор спирався не лише на свою пам'ять, яка й зараз у нього феноменальна (можу засвідчити це особисто, оскільки спілкувався з ним неодноразово), проглянув свої робочі записи, які вів 3 1965 року, використав деякі архівні документи, матеріали 3 Інтернету, звернувся за уточненнями до ветеранів органів внутрішніх справ. Особливу вдячність автор спогадів висловлює генерал-полковнику міліції, професору, доктору юридичних наук Сергію Миколайовичу Гусарову, що має великий досвід міліцейської та політичної діяльності, теж пройшов значний шлях служби в міліції - від рядового до генерала-полковника міліції, від інспектора - до першого заступника міністра внутрішніх справ (20032005 рр.), з яким він постійно обмінювався думками про тематику цієї книги і поради якого були корисними.

Міністри внутрішніх справ - це, перш за все, люди влади. Аеонід Кравчук у передмові до нашої з Олександром Бандуркою книги «Влада в Україні на зламі другого і третього тисячоліть» (2000р.) висловив багато в чому знакові, в тому числі і для себе, слова: «Влада чимось подібна сонцю. Вабить своїм блиском, може «пригріти», а може й спалити». Так сталося і з багатьма людьми, про яких згадує Олександр Бандурка. Пригріті «сонцем влади», вони відчули на собі і його палючість. Як пише автор рецензованої книги у Передньому слові до неї: «Людська доля міністрів була нелегкою. Кожний із них, будучи до призначення невідомим широкому загалу населення, ставши міністром, привертав до себе особливу увагу суспільства. Міністрів піддавали жорсткій 


\section{Рецензії, анотації}

критиці і образам, принижували їх людську гідність, звинувачували у вчиненні найтяжких злочинів».

Дуже цікавим є зауваження Олександра Бандурки щодо напрямів діяльності міністрів. «Кожний міністр, - пише він, - проявляв себе у якійсь сфері діяльності: в організаційній, виховній, ідеологічній, фінансово-господарській. Лише окремим із них вдалося проявити себе в основній функції міністра внутрішніх справ - правоохоронній». Це досить оригінальна оцінка, яка зразу ж відкидає усілякі думки про «лакування» портретів, упередженість чи заангажованість. Чому так сталося? Мабуть, це було пов'язано зі системою відбору кадрів на цю посаду, яка всі роки залишалася, перш за все, політичною, а вже потім професійною.

Починає свою оповідь Олександр Маркович 3 нарису про міністра внутрішніх справ УРСР О.М.Бровкіна. Працюючи над монографією з історії міліції, я теж ознайомився 3 деякими матеріалами про нього. У міліцію, точніше у МДБ, О. Бровкін прийшов з посади заступника завідувача відділом машинобудування ЦК КП(б)У і був призначений у жовтні 1951 р. заступником міністра державної безпеки УРСР. Aле після призначення міністром внутрішніх справ УРСР висуванця $\mathcal{A}$. Берії П.Я. Мешика у нього виник конфлікт з Бровкіним, і останній був усунутий $з$ посади і знову повернутий на партійну роботу. Щодо міністра П.Я. Мешика, то слід сказати, що він чимало зробив для українізації і не лише свого міністерства. Керуючись вказівками Берії, він дав наказ вести діловодство в МВС УРСР українською мовою, а від співробітників міністерства вимагав їі вивчення. П. Мешик особисто став розмовляти українською не тільки на нарадах у своєму міністерстві, а й в ЦК Компартії України. Один з найвідоміших працівників держбезпеки Павло Судоплатов згадував: «Хоча на засіданнях українського ЦК прийнято було розмовляти російською мовою, Мешик дозволив собі зухвало звернутися до присутніх українською мовою, порекомендувавши шокованим росіянам, зокрема i першому секретареві ЦК Мельникову, вчити українську мову». У Державному архіві СБУ зберігається цікавий документ - сте- нограма виступу П. Мешика на пленумі ЦК КПУ у червні 1953 р., де у кінці є примітка: «Переклад з української», тобто промову Мешика зафіксували українською, а потім для офіційної стенограми пленуму переклали російською.

Читаючи спогади Олександра Марковича, переконуєшся, що його професійні якості, що грунтуються на генетичному грунті батьківщини Богдана Хмельницького та Тараса Шевченка - рідній йому Черкащині, а також набуті багаторічною успішною роботою в МВС та Верховній Раді України, яскраво виявляються і у цих його нотатках. Коли він малює історичний портрет якогось міністра (як нам здається, це слово більш підходить для даного випадку, ніж слово «Пише»), то використовує для цього різні прийоми і засоби. Його мова жива і образна, насичена нетривіальними епітетами, метафорами, порівняннями, прикладами 3 класичної літератури та кіно. Тому й міністри дійсно виглядають як реальні люди, а не як парадні світлини, відретушовані місцевим фотографом для Дошки пошани. Ось чому поряд 3 портретом кожного міністра проглядає і портрет самого автора - досвідченого, мудрого, іноді трохи іронічного, наділеного почуттям гумору та певним особистим стилем, який не схожий ні на чий інший. Тут то й пригадується, що Олександр Маркович є членом Спілки письменників та Національної спілки журналістів України і, як показує дана книга, не за посадою, а за талантом. Тому він є дійсним иленом цих спілок, як це прийнято писати про академіків. (I він дійсно є також і академіком - Національної Академії правових наук України).

Ще одна відмітна риса спогадівO.М. Бандурки полягає в їх достовірності. Мені, як професійному історику, це особливо важливо. Адже хочеться, щоб спогади були не збіркою анекдотів та курйозів, а серйозним історичним джерелом. Візьмемо для прикладу постать міністра внутрішніх справ В.В. Федорчука. У своїх нотатках Олександр Маркович дає досить критичну характеристику цьому діячу. А що ж пишуть про нього інші відомі представники різних гілок влади того часу? Голова КДБ СРСР у 19611967 рр., колишній начальник В. Федорчу- 
ка, В.Ю. Семичастний: «До Федорчука я не дуже добре ставився». Колишній перший секретар ЦК КПУ П.Ю. Шелест: «Федорчук... займається невластивими справами: перевищенням влади, контрольними функціями за радянським і партійним апаратом». Секретар ЦК КПРС у 1983-1990 рр. С.К.Аігачов: "Дуже суха, бліда особистість 3 не дуже великим інтелектом». Як бачимо, оцінкиO.M. Бандурки повністю співпадають по суті 3 оцінками інших діячів. Роздуми викликало інше: як така особа ( не хочеться писати людина) як Федорчук, втративши сина (застрелився 3 його табельної зброї), дочку, дружину, відчуваючи зневагу і відчуженість колег, зміг прожити 90 років?

3 цікавістю прочитав сторінки книги, присвячені міністрові Ю.Ф. Кравченку. Непересічна особистість, загадкова смерть... Це, мабуть, найяскравіша особистість 3 міністрів внутрішніх справ України. Згадуючи про нього, Олександр Маркович пише: «Я пам'ятаю його перший приїзд до Харкова, до Національного університету внутрішніх справ, куди він був запрошений iз нагоди складання Присяги курсантамипершокурсниками. Тоді він буквально бігав по плацу, виглядаючи, чи не допустив хтось із присутніх офіцерів і курсантів якісь порушення форми одягу, чи нові на них емблеми, гудзики, нашивки.. Виявивши на місці порушення, давав команду звільнити того чи іншого з тих, хто, на свою біду, мав необережність потрапити під міністерську руку». Я тоді теж уже працював в Університеті внутрішніх справ і можу підтвердити, що так і було. Пригадується також, що одному з офіцерів, який найбільше сподобався міністру під час проходження маршем на плацу, він запропонував присвоїти достроково спеціальне звання «майор міліції». Як констатує О.М. Бандурка: «Так часто буває під час первинного сп'яніння владою» - і $з$ цим неможливо не погодити- ся. Я також був присутнім на захисті кандидатської дисертації Ю.Ф. Кравченком 28 грудня 1998 р., яка, до слова, пройшла не формально і тривала майже 4 години. Я до цього часу зберігаю його автореферат 3 дарчим написом та поздоровлення 3 Новим 1999 роком, яке він мені надіслав. Після захисту та численних питань Юрій Федорович, витираючи піт з обличчя, сказав: «Тепер я зрозумів, що таке кандидат наук». На всі питання він відповідав чітко, компетентно - видно, що знав про що говорить і цим справив дуже сприятливе враження.Я після цього був присутнім і на захистах деяких інших міністрів та їхніх заступників, але такого враження, як Ю.Ф. Кравченко, вони не справили. Тому цілком приєднуюся до висновку Олександра Марковича про те, що Ю.Ф. Кравченко «не допускав халтури в науковій роботі».

Так як я мав спеціальне звання «полковник міліції» і працював в установі, що належить до МВС України, мені довелося бути присутнім на зустрічах з різними міністрами внутрішніх справ республіки. Як науковець, я досліджую історію поліції і міліції в Україні (до слова, разом з автором рецензованих спогадів) і мав можливість вивчити біографії та діяльність багатьох народних комісарів та міністрів внутрішніх справ УРСР і України, а також СРСР протягом більш ніж 100 років. Звичайно, що у мене є і своє бачення, і оцінки діяльності деяких 3 вказаних особистостей, але вважаю, що дана робота написана в руслі історичної правди та $з$ позиції патріота України. Тому хочу зазначити, що книга спогадів Олександра Марковича Бандурки «Міністри теж люди» є важливим історичним документом, своєрідним пам'ятником тим людям, про яких він пише, тим більше, що багато хто 3 них вже пішов 3 життя. А для молодших і тих, хто мріє стати міністром, - хай це буде наука і уроки: яким треба бути міністром, а яким не треба. 